\title{
SUSTAINABLE DEVELOPMENT AND THE EXPLOITATION OF INDUSTRIAL MINERALS: THE PHOSPHATES PROJECT IN SAUDI ARABIA
}

\author{
DR. MOHAMMED ALDAGHEIRI \\ Department of Geography, Qassim University, Saudi Arabia.
}

\begin{abstract}
Mining is a vital sector in the economic development of many countries, including Saudi Arabia. At first glance, mineral-rich economies have an advantage over those less well endowed because minerals provide funds for rapid development and poverty reduction. Sustainable development requires recovery of resource revenue generated by mining, and investment of this revenue in other forms of wealth, capable of generating income and employment once minerals are depleted. The minerals sector in Saudi Arabia has great potential to play a leading role in diversifying the Saudi economy and has been regarded as a strategic factor for the inducement of future economic and industrial development in the country due to the Kingdom's enormous and relatively untapped mineral resource base, including precious and base minerals as well as industrial minerals. This article examines the phosphate project, which is considered as one of the industrial minerals important to the economy of the Kingdom of Saudi Arabia, focusing on its production, the structure of its industry and the effects of government policies and planning efforts.

Keywords: industrial minerals, phosphate, Saudi Arabia, sustainable development.
\end{abstract}

\section{INTRODUCTION}

According to the Saudi government, the mining sector has great potential to play a leading role in diversifying the Saudi economy. Mining is a vital sector in the economic development of countries such as Australia, Canada and Sweden, which largely depend on their natural resources for the development of their economies. Furthermore, it has been regarded as a strategic factor for the inducement of future economic and industrial sustainable development in the Kingdom due to the country's enormous and relatively untapped mineral resource base, including precious and base minerals as well as industrial minerals. There is also an increasing demand for raw materials in both domestic and international markets. Thus, the minerals sector has the potential to play a key role, but how will that potential be realized?

National economic diversification is considered a strategic goal for the Saudi Arabian government, particularly when the exportable natural resources are expected to deplete in the foreseeable future. The minerals sector in Saudi Arabia is one of the economic activities that have already started to achieve this strategic goal of diversification away from oil-related activities as the main source of national income. Although non-oil mineral activities are far less significant than oil activities, their development has the potential to contribute to the economic diversification of the Saudi economy. Exploration and development of non-hydrocarbon mineral resources has, therefore, been a consistent objective of the government throughout successive Development Plans.

The territory of the Kingdom contains abundant strategic minerals such as phosphate and bauxite, as well as industrial raw materials that can be used in the domestic, regional and overseas markets after processing. The diversified geological terrain, strong economy and strategic location of Saudi Arabia in the GCC countries are among the most fundamental 
features attracting investment in the mineral industry. Furthermore, it is hoped that this sector will become a major source of revenue generation for the Kingdom during the next decade. New mines and associated investments will also create employment opportunities in the Kingdom.

There is no doubt that the mining sector is considered the backbone of many countries. Furthermore, it has played an important role in the prosperity of nations, whether developed or developing. Saudi Arabia is one of these countries which have a large variety of metallic and non-metallic mineral resources that range in size and value estimate from limited potential to deposits large enough to sustain profitable exploitation. Mining is the key that converts mineral wealth into public infrastructures and other forms of capital that directly contribute to economic development [1]. According to Davis and Tilton [2], 'mining plays an important role in the development process by converting mineral resources into a form of capital that contributes to a nation's output'. Further, like other economic activities, mining plays an important role in the development process and can convert 'a mineral resource in the ground into sustainable improvements in people's lives' [3].

Regarding sustainability in the mineral sector, there is a famous and often-cited saying by Ahmed Zaki Yamani, who was Saudi Arabia's Oil Minister from 1962 to 1986 and a very prominent figure in OPEC, that 'The Stone Age came to an end not for the lack of stones and the oil age will end, but not for the lack of oil' [4]. This statement could imply that even though some resources are perceived as finite and extracting them as unsustainable, there are always opportunities for future societies to meet their needs by applying alternative resources or technology [5].

In addition to the extent of mineral resources over time, critical factors in understanding the sustainability of mining include environmental costs, namely solid waste burden; declining ore grades; energy, chemicals and water inputs; and pollution outputs, especially greenhouse emissions [6]. Therefore, the Saudi government needs to reinforce the capacity of the sectoral institutions to better regulate and promote the sustainable development of the sector. Moreover, the government also needs to empower them to overcome the administrative and legal complications that constrain private sector participation in the minerals sector through new mining codes which will streamline the procedures for obtaining licenses and will add more predictability and transparency.

\section{THE IMPORTANCE OF STUDY}

The Kingdom of Saudi Arabia is largely considered to be a single-commodity economy, in that the oil sector is the most important pillar of the national economy, while the non-oil sectors play a relatively weak role. National economic diversification is considered a strategic goal for the Saudi Arabian government. The minerals sector in Saudi Arabia is one of the economic activities which have already started to achieve this strategic goal of diversification away from oil-related activities as the only source of national income. Saudi Arabia has strategic industrial minerals such as phosphate, bauxite, high-grade silica and gypsum as well as industrial raw materials that can be used in the domestic, regional and overseas markets. The industrial minerals sector in Saudi Arabia recognizes sustainable development as a vital objective for society and readily acknowledges its responsibility for helping to achieve this critical aim. This article examines the Al-Jalamid phosphates project and considers the industrial mineral's importance to the economy of the Kingdom of Saudi Arabia, focusing on its production, the structure of its industry and the effects of government policies and planning efforts. 


\section{METHODOLOGY}

To assess the relationship between sustainable development and the minerals sector in Saudi Arabia and the role of government policies and planning efforts in the sector's development, and thus the problems and constraints that Saudi Arabia's minerals sector face, various methodologies have been used in this study. These methodologies were influenced by several variables related to the nature of this research. It is often very difficult to gather everything related to the subject under investigation, but sometimes it is impossible when the study relates to a developing country such as Saudi Arabia. Generally, research studies are conducted for the purpose of obtaining data that are not available from other sources regarding a specific area of knowledge.

Obtaining empirical data for this research has been achieved by using three different techniques: interviews, documentation and observation. The reason for using three methods is to gather as much information as possible about the evaluated project. Interviews provide indepth investigation, field observation provides information about the tasks and activities performed inside the project environment, and both documentation and archival records provide related documents which detail the project activities over the past years. Based on Yin [7], the various methods of collecting data are highly complementary to each other. Benbasat et al. [8] argue that these multiple sources of evidence aim to obtain a rich set of data surrounding the specific issue of research and capture the contextual complexity. However, the method selected depends on the goals and objectives of the research, the sample of respondents involved, the time set for the completion of the study and financial considerations.

The following municipalities and ministries have provided a variety of materials and data:

- Ministry of Petroleum and Minerals Resources (MPMR);

- Directorate General of Mineral Resources (DGMR);

- Deputy Ministry for Mineral Resources (DMMR);

- Ministry of Planning (MOP);

- Ministry of Information (MOI);

- Ministry of Finance and National Economy;

- King Abdulaziz City for Science and Technology (KACST);

- Saudi Geological Survey (SGS); and

- Saudi Arabian Mining Company (Ma’aden).

The data used in this research include numerous official documents and records that were obtained from various government and private sector departments. Needless to say, the Saudi Arabian Mining Company (Ma'aden), the SGS and the Ministry of Finance and National Economy came first, but other departments supplied a great deal of information concerning many aspects of the study. The most important of these data sources were the five National Development Plans (Ministry of Planning), the Statistical Yearbook series, the Private Establishments Census and the International Trade Statistics (Ministry of Finance and National Economy).

\section{THE ECONOMIC IMPORTANCE OF MINERALS}

The mining sector has played an important role in the prosperity of nations, whether developed or developing. This importance of minerals increased in the second half of the 19th century as the demand for high-grade industrial raw materials rose. There are about 50 countries in the world in which the mining sector plays an important role in the economy. Australia, 
Chile, Peru, USA, South Africa and Canada are the leading countries in today's global mining investment. The importance of minerals comes from the essential needs of manufacturing, construction, energy requirements and agriculture, and thus for the sustainable development of a modern economy.

Mining has played a vital role in the economic development of many South American countries, including Chile, Peru and Brazil. Relying on Global Development Network (GDN) [9], since 1990, Chile has been 'Latin America's star economy'. Chile was considered the largest copper producer in the world by 2008 , responsible for $34.2 \%$ of world production. From the perspective of world exports, Chile is the greatest exporter of copper in the world, with a participation in global exports that has varied between $37.8 \%$ and $40.4 \%$ over the last 10 years.

The mining sector contributes significantly to Peru's sustained economic growth. Peru hosts vast quantities of minerals such as gold, copper, silver, lead and zinc. After more than 20 years of isolation from direct foreign investment, the mining scene is changing as political and economic stability have brought renewed interest in Peru as a resource-rich investment opportunity for foreign companies. Most of the restrictions have been removed and the government has initiated a variety of incentives for foreign investments. Peru is now the world's number one producer of silver and second largest producer of copper, after Chile. Demand for Peruvian raw materials is set to grow rapidly in the coming years, where the scene is set for strong growth from the industry to 2014. Moreover, the sector will grow at an average rate of about $8.9 \%$ over the forecast period [10].

Brazil is considered one of the leading industrial nations in Latin America. In 2011, the Brazilian mineral production reached a new record of $\$ 50$ billion, which represents a $28 \%$ increase over the $\$ 39$ billion in 2010. Hence, in 2011 the Brazilian mineral production showed its recovery after the 2009 international economic crisis, which resulted in a decrease in demand for mineral raw materials. Brazil is the second largest producer of iron ore, and the production reached 372 million tonnes in 2010, equivalent to $15 \%$ of the world's total (2.4 billion tonnes). Furthermore, Brazil is the second largest producer of manganese ore, with approximately 2.6 million tons of concentrate in 2010, or $20 \%$ of the world's production of 13 million tons [11].

Minerals are a principle source of income for many developing countries in Africa as well. Africa is endowed with considerable amounts of mineral resources and ranks first or second in quantity of world reserves of bauxite, chromite, cobalt, industrial diamond, manganese, phosphate rock, platinum-group metals, soda ash, vermiculite and zirconium. The continent is also a major global producer of these minerals [12]. For example, the diamond remained the most important sector of the mining industry in Namibia, followed by uranium. Namibia is about to become one of the leading producers and exporters of uranium in the world; as a result, uranium mining will become a central feature of the Namibian economy. In Africa, Namibia might soon become the number one producer of uranium after Niger [13].

Mining is a vital sector in the economic development of many industrialized countries such as Australia, United States of America, United Kingdom, Canada and Sweden, which have largely depended on their natural resources for the development of their countries [14]. Based on the U.S. Geological Survey (USGS) [15], in 2011, the value of mineral production increased in the United States for the second consecutive year. Production increased modestly for most mineral commodities mined in the United States, and price increases, especially for precious metals, resulting in increases in the value of production. Minerals remained fundamental to the U.S. economy, contributing to the real gross domestic product (GDP) at 
several levels, including mining, processing and manufacturing finished products. Minerals' contribution to the GDP increased for the second consecutive year.

Australia is a world's leading mining nation and its minerals sector is Australia's premier global industry. The minerals industry's successful negotiation of the global financial crisis and its harnessing of the opportunities presented by renewed growth in global commodities demand have directly increased Australia's national income and wealth. The Australian mining industry:

- comprises about $8 \%$ of Australia's GDP and a similar share of total gross value added in the economy;

- invests about $15 \%$ of Australia's gross fixed capital formation;

- earns more than half of Australia's total export income - up from about a third early in the decade;

- is a major source of economic activity and jobs in regional and remote Australia.

Excluding oil and gas projects, committed projects in the sector amount to more than $\$ 40$ billion of investment, with an additional \$122 billion of less advanced projects [16].

The Kingdom of Saudi Arabia has natural resources that are highly diverse, both in terms of their variety and their location throughout the country. According to Dabbagh, the President and CEO of Ma'aden Company, 'The Arabian Shield rock formation in the west of the Kingdom is a little smaller than the Canadian Shield, and we are optimistic that it contains a similar amount of riches' [17]. Therefore, Saudi Arabia has a large variety of metallic and non-metallic mineral resources that range in size and value occurrences of limited potential to deposits large enough to sustain profitable exploitation.

\section{THE CONCEPT OF SUSTAINABLE DEVELOPMENT AND MINERALS SECTOR}

In spite of the term sustainable development now being widely used within government, business and the wider community, there is no generally accepted definition of sustainable development, and there is much debate about the scope and practical application of the concept. The classic definition of sustainable development, as stated by the Brundtland Commission, is development that meets the needs of the present without compromising the ability of future generations to meet their own needs [18]. However, there are some who argue that mining is fundamentally incompatible with sustainable development and can contribute negatively to sustainable development because it involves the extraction of non-renewable resources. From this perspective, the best that the industry can hope to do is to minimize its 'footprint' and improve resource efficiency. The alternative view is that mining can actually contribute positively to sustainable development by converting physical resources into new forms of economic and human capital, and by leaving a positive legacy in the areas where mining has taken place [19].

Relying on the report of Mining, Minerals and Sustainable Development Project (MMSD) [20], applying the concept of sustainable development to the minerals sector does not mean making one mine after another sustainable - whatever that means. The challenge of the sustainable development framework is to see that the minerals sector as a whole contributes to human welfare and well-being today without reducing the potential for future generations to do the same. Thus, the approach has to be both comprehensive, taking into account the whole minerals system, and forward looking, setting out long-term as well as short-term 
objectives. If the minerals sector is to contribute positively to sustainable development, it needs to demonstrate continuous improvement of its social, economic and environmental contribution, with new and evolving governance systems. The sector needs a framework within which it should judge and pursue any development. Using minerals to build a sustainable development requires some principles that help to implement the concept. These are:

- Adoption of a 'beyond compliance' philosophy by companies and individual sites.

- A strong focus on resource use efficiency and waste minimization (i.e. 'eco efficiency').

- Responsible stewardship of the natural environment.

- Mine closure policies that aim to leave a positive long-term legacy - both environmentally and socially.

- Responsible and safe workforce management practices.

- Sensitivity to local community concerns, combined with a commitment to advancing the long-term social and economic well-being of communities affected by mining.

- Integration of economic, social and environmental considerations into corporate decisionmaking processes.

- An understanding of the key challenges and constraints the sector facing at different levels and in different regions, and the actions needed to meet or overcome them along with the respective roles and responsibilities of actors in the sector.

- A process for responding to these challenges that respects the rights and interests of all those involved, that can set priorities and that ensures that action is taken at the appropriate level.

- An integrated set of institutions and policy instruments to ensure minimum standards of compliance as well as responsible voluntary.

- Verifiable measures to evaluate progress and foster consistent improvement.

- Policies that maximize resource revenue generated by mining.

- Recovery of resource revenue by an agency able and willing to reinvest revenue.

- Reinvestment of revenue in other assets that are capable of generating income and employment once resources are exhausted, such as human capital, public infrastructure and manufactured capital [21].

The minerals sector in Saudi Arabia has been regarded as a strategic factor for the inducement of future economic and industrial development in the country due to the Kingdom's enormous and relatively untapped mineral resource base. Thus, the minerals sector has the potential to play a key role in the national economy. The mining activities require appropriate environmental management in all fields particular to mineral exploration, processing, extraction and production. Therefore, economic and environmental issues must be considered when taking a decision related to any mining project, taking into account that mineral deposits are non-renewable. The community's social and economic needs must also be considered taking into account that such minerals, particularly non-metallic minerals, constitute huge reserves for the use of future generations through integrated and advanced programs and plans.

\section{THE PHOSPHATES IN SAUDI ARABIA}

Saudi Arabia is home to some of the largest phosphate deposits in the world. These deposits are located mostly in the north and north-western regions in a belt stretching across the entire northern section of the Kingdom (see Map 1). The phosphate rock is hosted in a sedimentary sequence of Paleocene to Eocene age that extends north into Iraq and Syria and west into 


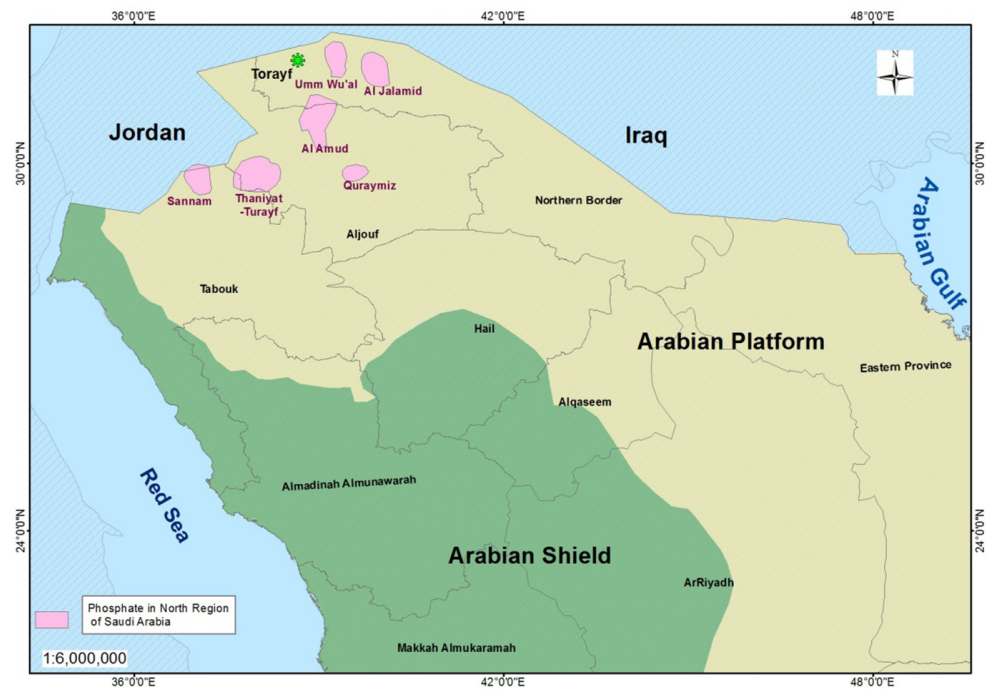

Map 1: Phosphate deposits in the North Region of Saudi Arabia.

Jordan. The phosphate reserves are part of a shelf sequence of rocks that mark the edge of the Tethys Sea, an ocean in past geological time that is now part of the Mediterranean and the countries surrounding its shores. It is the largest and most extensive phosphate province in the world [22].

The Kingdom's phosphate resource is estimated at 3.1 billion tonnes, of which 1.6 billion tonnes is an estimated reserve, with 1.5 billion tonnes as a mineable resource. In addition to the Al-Jalamid Mine Project, there is an estimated 313 million tonnes of phosphate ore reserve extending over an area of $18 \mathrm{~km}^{2}$. Spencer [23] stated that with private sector investment, Saudi Arabia can exploit the produced phosphate locally to consolidate its position as third ranked exporter of fertilizers in the world. Also, DMMR anticipates that the country will capture $16 \%$ of the world phosphate market. Identified future markets for phosphate include China, India, Japan, Pakistan and Iran.

Phosphate accumulations in Saudi Arabia are known in four regions: Sirhan-Turayf, the coastal Red Sea and the central and eastern regions. Deposits with economic potential have been established in the Sirhan-Turayf region that extends into Jordan, Syria and southern Iraq. Sedimentary phosphorite was first identified in Saudi Arabia in 1965 in the Turayf area during drilling for water wells by ARAMCO close to the Tapline, about $70 \mathrm{~km}$ to the east of Turayf city. In the same year, reconnaissance mapping led to another discovery of a phosphate bed in the Thaniyat-Turayf area, $250 \mathrm{~km}$ southwest of Turayf. In 1988, the Sannam deposit was discovered by the USGS and the DMMR. Furthermore, continued exploration works indicate prospects for other resources in the Widyan Ar-Rushaydah, Amud and AlFihah areas [24].

Al-Jalamid phosphate deposits are considered to be the best explored and largest deposits in the Kingdom, and are located about $120 \mathrm{~km}$ east-southeast of Turayf city. Since the discovery of the deposit in 1984, DMMR's work has advanced from the exploration phase to a feasibility study which was completed in late 1992. The Al-Jalamid deposit is estimated to contain 313 million tonnes of mineable resource. Ma' aden expects the Al-Jalamid deposit to 
have an annual yield of 11 million tonnes/year for 27 years, including 4.5 million tonnes of phosphate concentrates [25].

Al-Jalamid phosphate is the largest single project for the Ma'aden planners and is centred on a world-class deposit of phosphates. This resource could become a significant new source of exportable fertilizer in the form of diammonium phosphate (DAP), which contains double the nutrient value of unprocessed rock. This is a big project which would require the establishment of infrastructure for mining, processing and transport. Ma'aden estimates that the deposits within its exploration programs will lead to the establishment of a phosphate industry and a number of downstream industries in the Kingdom. Ma'aden views the phosphate resources of Al-Jalamid as a nucleus around which a number of industrial projects can be established.

Another resource prospect for phosphate mining in the Kingdom is the Umm Wu'al area, situated around $70 \mathrm{~km}$ west of the Al-Jalamid deposit. This deposit has been under extensive exploration indicating promising techno-economical potential with estimated reserves of about 208 million tonnes of phosphate deposits. Ma'aden, through international qualified consultants, has conducted the ore reserve evaluation and ore beneficiation and processing tests on both lab and pilot scales with objectives to assess the proven reserves, confirm the ore amenability to beneficiation and chemical processing and optimize its industrial flow sheets. The findings of these studies will be included in a feasibility study and utilized to identify local or foreign joint venture partners to develop this site.

Relying on the SGS, the Sanam phosphate beds correlate with the Thaniyat member of the Jalamid Formation and consist of two units. The area has not yet been explored in detail, but a resource study in 1999 showed a demonstrated resource of $23 \mathrm{Mt}$ averaging 16.91\%. A particular attraction of Sanam is its relative proximity to the Red Sea, $250 \mathrm{~km}$, in contrast to the $1000 \mathrm{~km}$ distance from Al-Jalamid to the Arabian Gulf. Thaniyat phosphate occurs at several levels in the Thaniyat Member at the base of the Jalamid Formation. Part of the Thaniyat area was explored under license by Granges International Mining in 1977-1981. The Al Amud phosphate beds of the Arqah Phosphorite Member in the Al Amud area are largely covered by basalt and have been explored by only 27 drill holes. In the Quraymiz area, there are two thin and low-grade phosphorite bed outcrops in an escarpment for about $20 \mathrm{~km}$ in the Quraymiz area. Six drill holes show no development of phosphorite beds to the north. Moreover, there are several areas in the Kingdom such as the Red Sea region (Maqna massif, Azlam trough and Usfan Area), Central region and Eastern region.

\section{AL-JALAMID PHOSPHATES PROJECT}

This project lies in the northern part of the Kingdom, about $150 \mathrm{~km}$ east-southeast of Turayf city. The feasibility study for this project was prepared by the Ma'aden-Saudi Oger consortium and S.N.C. Lavalin of Canada and Jacobs of the U.S., and according to Abdullah S. Busfar, vice-president for corporate projects [26], 'The project consists of a phosphate mine and a beneficiation plant at Al-Jalamid, in Northern Saudi Arabia, a fertilizer production complex at Ras Al-Khair, on the shore of the Arabian Gulf'.

The feasibility study indicates that the Al-Jalamid phosphate is estimated to contain 313 million tonnes of phosphates able to provide sustained production for at least 27 years. Also, the feasibility study indicates that 11 million tonnes of Al-Jalamid phosphate could be mined annually; upgrading the concentration of ore to $32 \%$, one could produce 4.5 million tonnes of phosphate concentrates [27] (Table 1). Ma'aden Company in June 2011 started initial production from the first production lines of sulphuric acid and phosphoric acid for captive use 
Table 1: Summary of phosphate deposits in North Region of Saudi Arabia.

\begin{tabular}{|c|c|c|}
\hline Phosphate deposits & Locations & Estimated (million tonnes) \\
\hline Al-Jalamid & $\begin{array}{l}150 \mathrm{~km} \text { east-southeast of } \\
\text { Turayf city }\end{array}$ & 313 \\
\hline Umm Wu'al & $\begin{array}{l}70 \mathrm{~km} \text { west of the } \\
\text { Al-Jalamid deposit }\end{array}$ & 208 \\
\hline Thaniyat-Turayf & $\begin{array}{l}250 \mathrm{~km} \text { southwest of Turayf } \\
\text { city }\end{array}$ & $\mathrm{X}$ \\
\hline Al Amud & $\begin{array}{l}200 \mathrm{~km} \text { southwest of the } \\
\text { Al-Jalamid deposit }\end{array}$ & 24 \\
\hline Sanam & $\begin{array}{l}\text { Proximity to the Red Sea, } \\
250 \mathrm{~km}\end{array}$ & 23 \\
\hline Quraymiz & $\begin{array}{l}190 \mathrm{~km} \text { east of } \\
\text { Thaniyat-Turayf deposit }\end{array}$ & $X$ \\
\hline
\end{tabular}

and DAP fertilizer, the final product, at its production complex in Ras Al-Khair. The production rate will be increased as other lines commence operation. According to Ma'aden, when at full production Ma'aden Company will produce approximately 3 million tonnes per year of DAP, which, according to the company's estimates, represents more than $10 \%$ of current global demand. Engr. Khalid Al Mudaifer, President and CEO of Ma'aden, said that 'The successful development of Ma'aden Company proves how such integrated minerals based projects can create value for shareholders, sustainable employment opportunities and regional development in the Kingdom.' He added, 'This complex operation is the largest fully integrated phosphate fertilizer project in the world and will place the Kingdom among the world leaders of the phosphate industry' [28].

Mining by its very nature can have a significant effect on the environment. Therefore, Ma'aden Company is committed to ensuring that all of its operations have the minimum possible effect on the environment both during and after the completion of mining activities in accordance with international environmental standards. Ma'aden has conducted a number of investigations and studies on the environmental effects of mining specifically on its new mining sites. These studies were conducted by internationally recognized specialist companies (SRK, GHD and SNC-Lavalin) under the supervision and support of Ma'aden.

The investigations took place over a number of years and included the following:

- The geological and topographical description of sites.

- Installation of meteorological equipment to observe weather conditions (temperature, wind speed and direction, solar heat radiation, relative humidity and rainfall).

- Analyses of air quality and polluting agents.

- Noise analyses.

- Comprehensive surveys of water sources (periodical analyses of underground and surface waters).

- Comprehensive survey and classification of soil.

- Comprehensive surveys and classification of wildlife and natural vegetation cover, and a 
study on the effects of mining on them.

- Comprehensive survey of socio-economics at the sites [29].

Ma'aden's operational teams invest considerable time, money and expertise in reducing the impact of their operations on the environment. For example, their water conservation practices include the following:

- Treatment of sanitary waste water at Al-Jalamid enables its re-use for irrigation.

- Implementation of a water recycling system at Al-Jalamid minimizes water consumption.

- Sanitary waste water at Ras Al Khair is tertiary treated and used for irrigation.

- Boiler blowdown from the sulphuric acid plant at Ras Al Khair is re-used at the phosphoric acid plant, reducing the amount of waste water generated and saving energy and resources for producing fresh process water.

- Hemihydrates technology used in the phosphoric acid plant achieves a 33\% reduction in water consumption compared to other technologies [30].

Regarding the environmental studies, consultants from Global Environmental Control Co. Ltd. came to the Al-Jalamid mine and conducted environmental measurements like gas testing, air dust measurements and noise survey at different locations at the mine. Furthermore, there are emission control efforts, where routine preventive maintenance services are performed on all heavy equipment and light vehicles, thus maintaining engine efficiency and reducing carbon monoxide emissions. Regular overhauling and PMS of power plant generators maintain operating efficiency and lessen if not eliminate unwanted gas emissions [31].

Usually, the environment faces some challenges during mining operations and industrial activity, such as dust and emissions of carbon monoxide, nitrogen oxides and sulphur air pollution [32]. Some studies have indicated contamination with heavy metals in the vicinity of the facilities mining areas [33]. Kennedy and Smith said that exposed micro-organisms to elevated concentrations of heavy elements are exposed to many of the metabolic stress that affects the activity of these organisms [34]. Oliver reached that the increase in the concentration of heavy elements lead to serious health problems if they leaked into the food chain [35]. Therefore, surface and subsurface samples were collected from the soil around the phosphate mine at Al-Jalamid. The samples were taken at 0, 1, 6, 10, 17, 20 and $28 \mathrm{~km}$ far from the mine in different geographic directions, and also samples were collected from different stages of rock phosphate treatment. Soil and rock phosphate samples were prepared for chemical and physical analyses.

Table 2 shows that the concentration of heavy elements $(\mathrm{Cd}, \mathrm{Co}, \mathrm{Cr}, \mathrm{Cu}, \mathrm{Fe}, \mathrm{Mn}, \mathrm{Ni}, \mathrm{Pb}$ and $\mathrm{Zn}$ ) in Al-Jalamid soils were within the limits of natural soils of the world, with a homogeneity in the concentrations of such metals either with depth, distances or with sampling direction. The con-centrations of heavy metals in Al-Jalamid soils are equal to their concentrations in the rock phosphate (especially cadmium and chromium). As the mining operations for rock phosphate increased the concentration of Cd increased from 0.3 to $1 \mathrm{mg} \mathrm{kg}^{-1}$, while $\mathrm{Zn}$ increased from 8 to $20 \mathrm{mg} \mathrm{kg}^{-1}$, in the rock phosphate and final product, respectively. However, this study recommends that there is a need for follow up of heavy metals concentrations in the dust and as well as in the soil, besides measuring the average annual plankton viable inhalation $(<10 \mathrm{~mm})$, and nitrogen oxides and carbon monoxide.

During the construction and commissioning phases of Al-Jalamid project, there are some impacts of the actual state on flora and fauna. Principally, these impacts will be direct, arising 
Table 2: Upper and lower limits and the average concentration of heavy metals in soils of Al-Jalamid Region in general.

\begin{tabular}{lllllll}
\hline \multirow{2}{*}{ Metal } & \multicolumn{2}{l}{$\begin{array}{l}\text { Concentration in the studying } \\
\text { soil }(\mathrm{mg} / \mathrm{kg})\end{array}$} & \multicolumn{3}{l}{$\begin{array}{l}\text { Common range in soils } \\
\text { (Lindsay, 1979) }(\mathrm{mg} / \mathrm{kg})\end{array}$} \\
\cline { 2 - 7 } & Max. & Min. & Mean & Max. & Min. & Mean \\
\hline $\mathrm{Cd}$ & 1 & 0 & 0.27 & 0.7 & 0.01 & 0.06 \\
$\mathrm{Co}$ & 8 & 1 & 5 & 40 & 1 & 8 \\
$\mathrm{~Pb}$ & 10 & 0 & 7 & 200 & 2 & 10 \\
$\mathrm{Cu}$ & 30 & 6 & 10 & 100 & 2 & 30 \\
$\mathrm{Ni}$ & 40 & 9 & 30 & 500 & 5 & 40 \\
$\mathrm{Zn}$ & 70 & 10 & 30 & 300 & 10 & 50 \\
$\mathrm{Cr}$ & 40 & 9 & 30 & 1000 & 1 & 100 \\
$\mathrm{Mn}$ & 300 & 40 & 200 & 3000 & 20 & 600 \\
$\mathrm{Fe}$ & 20000 & 2000 & 9000 & 550000 & 7000 & 38000 \\
\hline
\end{tabular}

Source: Al-Shammari et al. [36].

from site clearance works, cut and fill operations, the temporary stockpiling of materials and the diversion of Wadi drainage channels for flood protection works. Regarding flora, the study area is characterized by its sparse, patchy dwarf shrub vegetation, concentrated in small drainage lines, wadis and silty depressions. There are no trees, except for the occasional Tamarix arborea along large stream beds near the mine. Dominant perennial shrub species include Haloxylon salicornicum, Salsola spp., Artemisia spp., Achillea fragrantissima and Astragalus trimestris. Zilla spinosa and Capparis spinosa are abundant on the margins of silty depressions. Perennial grasses, which include several Stipagrostis spp. are sparsely distributed and poorly represented, probably due to intensive sheep and camel grazing in some areas. Chert/gravel plains and rocky basalt slopes and jabals support few perennial plants. A community of Haloxylon persicum and Calligonum comosum grows on mobile sand drifts. The plant species and communities within the project area will vary spatially and temporally subject to seasonal variations such as rainfall, temperature and geophysical variations. The condition of plants was qualitatively assessed based on chlorophyll content of plants, and no significant variation was observed between the three different visits. Flora within the study area are valued at the national level based on the Northern Wildlife Management Zone designation. In terms of the assessment of impact, impacts on flora have been combined with impacts on habitat.

With respect to fauna in Al-Jalamid project, the site clearance and cut and fill operations to facilitate the project during the construction phases have the potential to kill and injure mammal, bird and reptile species. Impacts are likely to arise from the direct damage and destruction to places of rest and shelter, breeding sites and nesting sites. There is also an increased risk that faunal species could be involved in collisions with construction vehicles as a consequence of increased road traffic and vehicle movements. Data were collected on many species of large and small mammal during the survey, in addition to 72 species of birds 
and 11 species of reptile. However, a number of globally and regionally threatened species that have been recorded as being present, or their presence indicated from anecdotal evidence could be impacted. This includes the Arabian wolf (Regionally Endangered), sand cat (Globally Near Threatened), Blanford's fox (Regionally Vulnerable) and the Egyptian spiny tailed lizard (Globally Vulnerable). In addition, the Houbara bustard (globally vulnerable) may potentially breed within the area of the project and this is a ground nesting species. Furthermore, the Egyptian spiny tailed lizard is less mobile than the other species and tends to construct its burrows in areas where there is persistent vegetation through the summer months and from where they do not stray too far. For this reason, there is a particular risk of killing and injuring this species during flood protection works and other impacts to wadi drainage channels. Therefore, potential impacts of killing and injury on these threatened species during the construction and commissioning phases of the project are assessed as highly adverse significant [37].

Keenly aware of its responsibility as Saudi Arabia's pre-eminent mining company and the important role that mining and related industries are set to play in the Kingdom's industrial growth, Ma'aden invests heavily in Saudization, training Saudi nationals for careers in mining and doing business with local suppliers. Despite many aspects of Ma'aden's business being new to the country and highly technical, Ma'aden's overall Saudization rate at the end of 2011 was $63 \%$. This program is part of the company's long-term plan to increase its number of employees to 6500 by 2015 with a targeted Saudization rate of up to $80 \%$. This translates to about 900 jobs per year to be added across Ma'aden's subsidiaries [38].

Engr. Khalid Al Mudaifer, President and CEO, commented that 'Ma' aden is committed not only to tapping the Saudi labour market to keep pace with the Kingdom's Saudization programme but also in providing the technical know-how to meet industry requirements'. He added: 'Our training programme reflects Ma'aden's drive to achieve sustainable development and promotes its policy on social responsibility with emphasis on areas where it operates, in line with the national development' [39].

The phosphate rock is transported via the North-South Railway (NSR) to the industrial city of Ras Al-Khair for conversion into DAP fertilizer for export. The Ras Al-Khair site is about $60 \mathrm{~km}$ north of Jubail Industrial City on the Arabian Gulf. Ras Al-Khair is a huge new industrial centre designed to serve the Kingdom's emerging minerals sector and has an $\$ 8$ billion investment, which comprises the industries of the phosphate and aluminium projects. The main elements of the industrial centre at Ras Al-Khair are three 4.1 million tons per year sulphuric acid plants, three 1.4 million tons per year phosphoric acid plants and one 650,000 tons per year ammonia plant, to produce about 2.9 million tons per year of DAP. The basic infrastructure of the industrial centre includes accommodation and utility services, port facilities, a $1800 \mathrm{MW}$ power plant, sub-stations and switchgear plus a dedicated port for Panamax-sized ships of up to 60,000 tons [40].

The estimated cost of the phosphate projects at Ras Al-Khair is around \$1.9 billion, plus additionally about $\$ 400$ million to develop the mines at the Al-Jalamid site. In an interview, the President of Ma'aden Dr. Al-Dabbagh said that the availability of molten sulphur and natural gas from within the Kingdom as a feedstock alongside the local phosphate rock will make it a highly competitive integrated production facility within easy reach of growing Asian markets. Ma'aden intends to use the phosphate rock in the production of a number of value-added products, such as fertilizers, chemicals, animal feed and detergents [41]. Ma'aden's Chairman, Engr. Abdullah Saif Al Saif, said, 'We look forward to increasing food security in India through an expanding flow of high quality product from Ma'aden's world 
scale phosphate resources and operations'. The CEO Engr. Mudaifer added, 'Our strategy is to become one of the largest phosphate producers in the world. That our neighbour India is the world's largest importer of DAP is evidence of the strategic importance of India to Ma'aden. To have such great demand, located so close to Saudi Arabia's abundant resources, shows why this relationship is so important' [42].

In general, the development of the Al-Jalamid phosphate project relies on the following comparative advantages:

- Availability of abundant low-cost energy in the form of petroleum and natural gas products.

- Availability of ammonia at competitive prices in Jubail.

- Availability of abundant sulphur in Jubail.

- Geographic proximity of the Jubail complex to the Asian markets.

- Market opportunities following the decline of production in Florida, which has decreased by one-third during the past decade.

- Approval of the necessary transport link between the Al-Jalamid phosphates deposits and Ras Al-Khair.

The development initiation of Al-Jalamid integrated phosphate project will be beneficial due to the following:

1. Maintenance of the Kingdom's future export capability through diversification of its products where the huge phosphate resources will play a major element.

2. Employment opportunities for the Saudi work force, which is expected to directly employ about 6000 personnel.

3. Indirect benefits to Saudi work force and institutions through related industrial and social services, employing about 4000 personnel.

4. Enhanced urban development in the Northern Region.

5. Transfer of technology in the field of phosphate fertilizers and other related chemical industries.

6. Enhanced foreign capital investment [43].

\section{CONCLUSIONS}

Mining is a vital sector in the economic development of countries such as Australia, Canada and Sweden, which largely depend on their natural resources for the development of their economies. The minerals sector in Saudi Arabia has great potential to play a leading role in diversifying the Saudi economy and has been regarded as a strategic factor for the inducement of future economic and industrial development in the country due to the Kingdom's enormous and relatively untapped mineral resource base, including precious and base minerals as well as industrial minerals.

Regarding the significance of the minerals industry, the case study has shown that the mining sector has great potential to play a leading role in the sustainable development and the diversification of the Saudi economy due to the Kingdom's enormous and relatively untapped mineral occurrences, large area (more than two million square kilometres) and the increasing demand for raw materials in both domestic and international markets. The minerals industry in Saudi Arabia, which includes phosphate, could become one of the main activities attracting foreign investment, and during the next decade it is hoped it will be one of the causes of con- 
siderable economic growth in the region and the country. The minerals sector will become a third pillar of the economy after hydrocarbons and petrochemicals. The mineral industry will also have several positive effects on the national economy, such as constituting a source of additional revenue for the government, increasing exports and contributing to export diversification, creating new opportunities for the creation of industrial activities in the Kingdom.

This article concludes that the aim of the Saudi government is to develop integrated downstream clusters of industry in the minerals sector, thus making the country a leading exporter in that regard. It therefore fulfils the very first criteria of processing the raw material into value-added products instead of exporting the raw materials for processing in more developed countries. The value addition that is taking place in the developed countries should in future take place in Saudi Arabia itself. Also, Saudi Arabia has other advantages over the developed countries which dominate the world minerals industry, such as the location factor in terms of plant site close to input resources and the geographic proximity of Asian markets.

Al-Jalamid phosphates could play a major role in the Kingdom's future exports. This project will enhance urban development in the Northern Region of the Kingdom. The phosphate industry provides a transfer of technology in the field of phosphate fertilizers and other related chemical industries. According to Ma'aden's estimates, the phosphate fertilizer, with encouraging economic indicators, would make the Kingdom the world's third largest producer of phosphate fertilizer. According to Ma'aden, the minerals industry will create employment opportunities which will generate 6000 direct jobs and 40,000 indirect jobs for Saudi citizens who will work in the building and operating of the industry and associated projects.

\section{REFERENCES}

[1] Davis, G. \& Tilton, J., The resource curse, Natural Resources Forum, 29, pp. 233-242, 2005. doi: http://dx.doi.org/10.1111/j.1477-8947.2005.00133.x

[2] Davis, G. \& Tilton, J., Should Developing Countries Renounce Mining? A Perspective on the Debate, Colorado School of Mines: Colorado, 2002.

[3] Togolo, M., Mining and sustainability - Placer Niugini Limited. PACRIM '99, Proceedings of International Conference on Earth Science, Exploration and Mining Around the Pacific Rim, Bali, Indonesia, 1999.

[4] Leggett, J., Half Gone: Oil, Gas, Hot Air and the Global Energy Crisis, Portobello Books: London, UK, 2005.

[5] Mudd, G. \& Ward, J., Will sustainability constraints cause 'peak minerals'? 3rd International Conference on Sustainability Engineering and Science: Blueprints for Sustainable Infrastructure', Auckland, New Zealand, December 2008.

[6] Mudd, G., The Sustainability of Mining in Australia: Key Production Trends and Their Environmental Implications for the Future, Research Report No. RR5, Department of Civil Engineering, Monash University and Mineral Policy Institute, October 2007.

[7] Yin, R., Case Study Research - Design and Methods, Sage: London, 1994.

[8] Benbasat, I., Goldstein, D. and Mead, M., The case study research strategy in studies of information systems. MIS Quarterly Archive, 11(3), pp. 369-386, 1987. doi: http:// dx.doi.org/10.2307/248684

[9] Global Development Network (GDN), Role of Copper in the Chilean \& Zambian Economies: Main Economic and Policy Issues, Working Paper No. 43, 2011.

[10] Business Monitor International, Peru Mining Report, Business Monitor International, London, 2012. 
[11] The Brazilian Mining Association, Information and Analyses of The Brazilian Minerals Economy, 6th edn, The Brazilian Mining Association: Brasilia, 2011.

[12] The United Nations Economic Commission for Africa (UNECA), Mineral Resources for Africa's Development: Anchoring a New Vision, Eighth African Development Forum (ADF-VIII), Addis Ababa, Ethiopia, October 2012.

[13] Shindondola-Mote, H., Uranium Mining in Namibia: The Mystery behind 'Low Level Radiation', Labour Resource and Research Institute: Namibia, 2009.

[14] Alfi, K. \& Zagan, A., The role of mining sector in the diversification of Saudi Economy. Saudi Economic Survey, 38(1860), pp. 48-56, 2004.

[15] U.S. Geological Survey (USGS), Mineral Commodity Summaries 2012, USGS: Reston, VA, 2012.

[16] Minerals Council of Australia, Exploration Policy: A Response to the Policy Transition Group Issues Paper, Minerals Council of Australia, 2010.

[17] Dabbagh, A., Saudi Arabia to offer gold mining licenses to foreign firms, Ma'aden News Letter, Riyadh, Saudi Arabia, 2004.

[18] World Commission on Environment and Development, Our Common Future, Oxford University Press: Oxford, 1987.

[19] Brereton, D., Promoting sustainable development in the minerals industry: a multi-disciplinary approach, Paper Presented at the Annual Conference of the Australasian Association for Engineering Education, Melbourne, 2003.

[20] Mining, Minerals and Sustainable Development Project (MMSD), Breaking New Ground, The Report of the Mining, Minerals and Sustainable Development Project, Earthscan Publications: London, 2002.

[21] Lange, G.-M., The contribution of minerals to sustainable economic development: mineral resource accounts in Namibia, DEA Research Discussion Paper 54, 2003.

[22] Ma'aden, Exploration, mining and processing, Ma'aden Magazine, Riyadh, Saudi Arabia, 2004.

[23] Spencer, H., Industrial minerals of Saudi Arabia and their uses in new material, Internal Report, Jeddah: DMMR, 1999.

[24] DMMR, The Developing of Mineral Exploration in the Kingdom, Ministry of Petroleum and Mineral Resources: Jeddah, Saudi Arabia (in Arabic), 1999.

[25] USABC, The mining sector in the Kingdom of Saudi Arabia, Report, U.S.-Saudi Arabian Business Council, 2005.

[26] Busfar, A., Maaden to build the largest phosphate plant in 2005, Arab News, March 01, 2005.

[27] Ma'aden, Exploration, mining and processing, Ma'aden Magazine, Riyadh, Saudi Arabia, 2004.

[28] Ma'aden, Ma'aden Starts Initial Production of DAP, Saudi Arabian Mining Company: Riyadh, Saudi Arabia, 2011.

[29] Ma'aden, Our Commitment to Corporate Social Responsibility, Saudi Arabian Mining Company, available at http://www.maaden.com.sa/en, 2013.

[30] Ma'aden, Annual Report - 2011, Saudi Arabian Mining Company: Riyadh, Saudi Arabia, 2011.

[31] Saudi Arabian Mining Company, Ma'aden, Annual Report - 2012, Saudi Arabian Mining Company: Riyadh, Saudi Arabia, 2012 (in Arabic).

[32] International Fertilizer Industry Association and the United Nations Environment Program (IFA-UNEP), Environmental Aspects of Phosphate and Potash Mining, International Fertilizer Industry Association: Paris, 2001. 
[33] Baker, B.J., Copper in Heavy Metals in Soils, ed. B.J. Alloway, John Wiley and Sons: New York, 1990.

[34] Kennedy, A.C. \& Smith, K.L., Soil microbial diversity and the sustainability of agricultural soils, Plant and Soil Journal, 170: pp. 75-86, 1995. doi: http://dx.doi.org/10.1007/ BF02183056

[35] Oliver, M.A., Soil and human health: a review. European Journal of Soil Science, 48(4), 1997. doi: http://dx.doi.org/10.1046/j.1365-2389.1997.00124.x

[36] Al-Shammari, N., Al-Farraj, A. \& El-Maghraby, S., A base line study for heavy metals concentration in the soils around phosphate mine at Hazm Al Galamed - Saudi Arabia. Agricultural Sciences Journal, 2012.

[37] Ma'aden, Umm Wu'al Environmental and Social Impact Assessment, Saudi Arabian Mining Company: Riyadh, Saudi Arabia, 2013.

[38] Ma'aden, Annual Report - 2011, Saudi Arabian Mining Company: Riyadh, Saudi Arabia, 2011.

[39] Ma'aden, Ma'aden Plans to Add 900 New Jobs Annually, Targeting 6,500 Employees by 2015, Saudi Arabian Mining Company: Riyadh, Saudi Arabia, 2012.

[40] Ma'aden, Al-Naimi inaugurates mining city civil works, Ma'aden News Letter, Issue 4, 2005.

[41] Al-Naimi, A., \$4.1b Phosphate Ventures Open to Foreign Investors, the Saudi Gazette, March 28, 2004.

[42] Ma'aden, Ma'aden Strengthens Ties with Indian Phosphate Market, Saudi Arabian Mining Company: Riyadh, Saudi Arabia, 2011.

[43] Ma' aden, Annual Report - 2012, Saudi Arabian Mining Company: Riyadh, Saudi Arabia, 2012 (in Arabic). 